Edutainment : Jurnal Ilmu Pendidikan dan Kependidikan

Volume 8 No. 1 Edisi Januari - Juni 2020

\title{
PENANAMAN NILAI-NILAI PENDIDIKAN KARAKTER MELALUI PEMBELAJARAN MENULIS PUISI DENGAN MENGGUNAKAN MODEL MIND MAPPING
}

\author{
Budi Utomo \\ SMA Negeri 2 Sungaiselan \\ budhy.azzahra@gmail.com
}

\begin{abstract}
Abstrak
Penelitian ini dilatarbelakangi oleh munculnya nilai - nilai karakter dalam diri siswa di SMA Negeri 2 Sungaiselan melalui pembelajaran. Penelitian ini bertujuan untuk menanamkan nilai nilai pendidikan karakter melalui pembelajaran menulis puisi dengan Model Mind Mapping di kelas XII SMA Negeri 2 Sungaiselan. Penelitian ini menggunakan metode penelitian kualitatif deskriptif. Subjek penelitian ini yaitu siswa kelas XII berjumlah 20 siswa. Teknik pengumpulan data menggunakan teknik tes unjuk kerja, observasi, serta wawancara. Teknik analisis menggunakan analisis data model Miles and Huberman melalui tiga tahapan, yakni reduksi data (data reduction), penyajian data (display data), dan kesimpulan (conclusion drawing/ verification). Hasil yang diperoleh selama pembelajaran menulis puisi menggunakan model Mind Mapping untuk menanamkan nilai-nilai pendidikan karakter di kelas XII Bahasa SMA Negeri 2 Sungaiselan bahwa siswa menunjukkan sikap/perilaku yang positif. Tampak selama pembelajaran rasa ingin tahu yang tinggi sebesar 79,8\%, disiplin sesuai aturan yang disepakati $85 \%$, jujur dalam menulis $75,4 \%$, kreatif $74,3 \%$, mandiri dan bertanggung jawab $89 \%$. Hasil cipta puisi menunjukkan karakter dari para penulis, karena selama pembelajaran berlangsung siswa dituntut untuk jujur dan bertanggung jawab.
\end{abstract}

Kata Kunci: Model Mind Mapping; nilai-nilai endidikan Karakter; Puisi.

\begin{abstract}
The motivation of this research was the emergence of students' character values through learning in SMA Negeri 2. This study aims to instill the values of character education through learning to write poetry with the Mind Mapping Model in class XII of SMA Negeri 2 Sungaiselan. This research used descriptive qualitative research methods. The subjects of this study were 20th grade XII students. Data collection techniques used performance test techniques, observation, and interviews. The analysis technique used data analysis of the Miles and Huberman model through three stages; data reduction, data display (data display), and conclusion (conclusion drawing/verification). The results obtained during learning to write poetry using the Mind Mapping model to instill the values of character education in Language class XII Sungaiselan High School 2 showed a positive attitude/behavior. The study result found a high curiosity (79.8\%), discipline to agreed rules (85\%), honesty in writing (75.4\%), creative (74.3\%), independent and responsible (89\%). The creation of poetry showed the character of the writers because during the learning process students are required to be honest and responsible.
\end{abstract}

Keywords: Mind Mapping Model; Character Education Values; Poems. 


\section{PENDAHULUAN}

Sekolah merupakan rumah kedua bagi anak untuk mendapatkan didikan pengetahuan dan mental melalui para pendidik. Dari didikan tersebutlah terbentuk berbagai karakter anak. Sejumlah karakter yang muncul diharapkan dapat menciptakan sekolah yang aman dan nyaman serta menyenangkan. Demi terciptanya harapan tersebut, Kementerian Pendidikan dan Kebudayaan RI telah mengeluarkan lima regulasi, diantaranya: Permendikbud No. 23 Tahun 2015, Permendikbud No. 64 Tahun 2015, Permendikbud No. 82 Tahun 2015, Permendikbud No. 8 Tahun 2016, dan Permendikbud No. 18 Tahun 2016.

Membentuk generasi muda yang memiliki pengetahuan dan mental sudah berhasil dilakukan dalam proses pendidikan di Indonesia. Tercermin dari prestasi yang diraih oleh putra - putri bangsa di tingkat Internasional, seperti meraih medali emas dalam ajang olimpiade sains dan matematika, menjadi juara kompetisi robot dan lomba karya ilmiah. Walaupun demikian, pendidikan di Indonesia belum mampu membangun karakter bangsa. Hal ini dapat dilihat dari maraknya tawuran remaja, seks bebas, pejabat yang korupsi, dan penyalahgunaan narkoba (Astawa, 2018:1-2).
Merujuk permasalah tersebut, pemerintah kembali mengeluarkan regulasi terkait pembentukan karakter dalam pendidikan yang tercantum pada Perpres No. 87 Tahun 2017 tentang Penguatan Pendidikan Karakter.

Penguatan Pendidikan Karakter (PPK) merupakan gerakan pendidikan di bawah tanggung jawab satuan pendidikan untuk memperkuat karakter peserta didik melalui harmonisasi olah hati, olah rasa, olah pikir, dan olahraga dengan pelibatan dan kerja sama antara satuan pendidikan, keluarga, dan masyarakat sebagai bagian dari Gerakan Nasional Revolusi Mental (GNRM).

Kementerian Pendidikan Nasional dalam Salahudin (2013:54-56) menyatakan nilai karakter bangsa terdiri dari beberapa kategori sebagai berikut: Religius yaitu sikap/perilaku yang patuh dalam melaksanakan ajaran agama yang dianutnya, dan toleran terhadap pelaksanaan ibadah agama lain, serta hidup rukun dengan pemeluk agama lain. Jujur yaitu perilaku yang didasarkan pada upaya menjadikan dirinya sebagai orang yang selalu dapat dipercaya dalam perkataan, tindakan, dan 
Edutainment : Jurnal Ilmu Pendidikan dan Kependidikan

Volume 8 No. 1 Edisi Januari - Juni 2020

pekerjaan. Toleransi yaitu sikap dan tindakan yang menghargai perbedaan agama, suku, etnis, pendapat, sikap, dan tindakan orang lain yang berbeda dari dirinya. Disiplin yaitu tindakan yang menunjukkan perilaku tertib dan patuh pada berbagai ketentuan dan peraturan. Kerja keras yaitu perilaku yang menunjukkan upaya sungguhsungguh dalam mengatasi berbagai hambatan belajar dan tugas, serta menyelesaikan tugas dengan sebaik-baiknya. Kreatif yaitu berpikir dan melakukan sesuatu untuk menghasilkan cara/hasil baru dari sesuatu yang telah dimiliki. Mandiri yaitu sikap dan perilaku yang tidak mudah bergantung pada orang lain dalam menyelesaikan tugas-tugas.

Demokratis yaitu cara berpikir, bersikap, dan bertindak yang menilai sama hak, serta kewajiban dirinya maupun orang lain. Rasa ingin tahu yaitu sikap/tindakan yang selalu berupaya untuk mengetahui lebih mendalam maupun meluas dari sesuatu yang dipelajarinya, dilihat, dan didengar. Semangat kebangsaan yaitu cara berpikir, bertindak, dan berwawasan yang menempatkan kepentingan bangsa dan negara di atas kepentingan diri dan kelompoknya. Cinta tanah air yaitu cara berpikir, bersikap, berbuat yang menunjukkan kesetiaan, kepedulian, penghargaan yang tinggi terhadap bahasa, lingkungan fisik, sosial, budaya, ekonomi, dan politik bangsa. Menghargai prestasi yaitu sikap/tindakan yang mendorong dirinya untuk menghasilkan sesuatu yang berguna bagi masyarakat, dan mengakui, serta menghormati keberhasilan orang lain. Bersahabat/komunikatif yaitu tindakan yang memperlihatkan rasa senang berbicara, bergaul, dan bekerja sama dengan orang lain. Cinta damai yaitu sikap, perkataan, tindakan yang menyebabkan orang lain merasa senang, dan aman atas kehadiran dirinya. Gemar membaca yaitu kebiasaan menyediakan waktu untuk membaca berbagai bacaaan yang memberikan manfaat bagi dirinya. Peduli lingkungan yaitu sikap/tindakan yang berupaya mencegah kerusakan lingkungan alam disekitarnya, dan mengembangkan upaya-upaya untuk memperbaiki kerusakan alam yang sudah terjadi. Peduli sosial yaitu sikap/tindakan yang selalu ingin memberi bantuan pada orang lain dan masyarakat yang membutuhkan. Tanggung jawab yaitu sikap/perilaku seseorang untuk melaksanakan tugas maupun kewajibannya, yang seharusnya dia lakukan terhadap diri sendiri, masyarakat, lingkungan (alam, karakter dimulai dalam sosial dan budaya), negara dan Tuhan Yang Maha Esa. 
Edutainment : Jurnal Ilmu Pendidikan dan Kependidikan

Volume 8 No. 1 Edisi Januari - Juni 2020

SMA Negeri 2 Sungaiselan Kabupaten Bangka Tengah Provinsi Kepulauan Bangka Belitung merupakan salah satu sekolah yang telah menyusun dan menerapkan program pendidikan karakter, misalnya melaksanakan shalat berjamaah di masjid bagi yang beragama Islam, membaca buku/ayat suci 15 menit sebelum pembelajaran dimulai, menjalankan program kewirausahaan, Jumat Bersih (gotong royong membersihkan lingkungan sekolah dan tempat-tempat ibadah), dan sebagainya. Namun dalam program yang dijalankan belum begitu maksimal dalam menanamkan pendidikan karakter kepada siswa. Hal tersebut terlihat dari perilaku siswa yang belum disiplin, membuang sampah tidak pada tempatnya, selalu berbeda pendapat, belum menjalankan tugas dan kewajibannya dengan baik.

Siswa sebagai produk pendidikan secara kemanusiaan dan kepribadian masih terlihat lemah, sehingga mudah terpengaruh oleh budaya negatif yang datang dari luar. Selain itu, semangat untuk belajar, berdisiplin, beretika, bekerja keras, dan sebagainya kian menurun. Hasil wawancara terhadap siswa diperoleh berbagai penyebab munculnya permasalahan tersebut diantaranya: 1) pemberian sanksi kepada siswa yang datang terlambat masih samar-samar atau tidak bertindak tegas dan tidak merata, sehingga mendatangkan kecemburuan antar siswa yang diberi dan tidak diberi sanksi; 2) pembelajaran yang bersifat monoton, guru mengajar terpaku pada buku teks. Salah satu solusi yang telah dilakukan untuk mengatasi permasalahan di atas yaitu melalui pembelajaran sastra.

Dalam kurikulum 2013 disebutkan bahwa tujuan pembelajaran sastra dalam mata pelajaran Bahasa Indonesia yaitu menikmati dan memanfaatkan karya sastra untuk memperluas wawasan, memperhalus budi pekerti, serta meningkatkan pengetahuan dan kemampuan berbahasa. Melalui apresiasi sastra, siswa dapat mempertajam perasaan, penalaran, daya khayal, serta kepekaan terhadap masyarakat, budaya, dan lingkungan kehidupannya.

Sastra dalam banyak hal memberi peluang kepada pembaca untuk mengalami posisi orang lain, yang menjadikannya berempati kepada nasib dan situasi manusia lain. Melalui sastra, seseorang dapat menjadi seorang dokter, guru, gelandangan, tukang becak, ulama, ronggeng, pencuri, pengkhianat, pengacara, rakyat kecil, pejabat, dan sebagainya.

Pembelajaran sastra yang dilakukan berbantuan model Mind Mapping dalam menulis puisi. Mind Mapping bisa disebut sebuah peta rute yang digunakan ingatan, 
Edutainment : Jurnal Ilmu Pendidikan dan Kependidikan

Volume 8 No. 1 Edisi Januari - Juni 2020

membuat kita bisa menyusun fakta dan fikiran sedemikian rupa, sehingga cara kerja otak kita yang alami akan dilibatkan sejak awal, sehingga mengingat informasi akan lebih mudah dan bisa diandalkan daripada menggunakan teknik mencatat biasa.

Mind Mapping disebut pemetaan pikiran atau peta pikiran, yakni salah satu cara mencatat suatu materi pelajaran yang memudahkan siswa untuk belajar. Mind Mapping bisa juga dikategorikan sebagai teknik mencatat kreatif. Dalam penjelasan yang lebih sederhana, peta pikiran (Mind Mapping) adalah satu teknik mencatat yang mengembangkan gaya belajar visual. Peta pikiran memadukan dan mengembangkan potensi kerja otak yang terdapat di dalam diri seseorang.

Mind Mapping diterapkan untuk penanaman konsep serta meningkatkan kreativitas siswa dalam pembuatan puisi yang bernilai pendidikan karakter dalam mata pelajaran Bahasa Indonesia, agar siswa lebih mudah untuk mengingat materi yang diajarkan, dengan Model Mind Mapping siswa lebih mampu mengonstruksi informasi - informasi yang telah diperoleh.

Berdasarkan latar belakang tersebut, maka rumusan masalah penelitian ini: bagaimanakah penanaman nilai - nilai pendidikan karakter melalui pembelajaran menulis puisi dengan menggunakan model Mind Mapping di kelas XII SMA Negeri 2 Sungaiselan? Berdasarkan rumusan masalah tersebut, maka tujuan penelitian ini untuk mendeskripsikan penanaman nilai - nilai pendidikan karakter melalui pembelajaran menulis puisi dengan menggunakan model Mind Mapping di kelas XII SMA Negeri 2 Sungaiselan.

Hasil penelitian ini dapat memberikan berbagai manfaat, yakni bagi siswa, hasil penelitian ini dapat mencipta puisi yang bernilai pendidikan karakter, sehingga pembelajaran dapat menjadi pembelajaran yang bermakna. Bagi guru dari penelitian ini diharapkan guru dapat menggunakan model pembelajaran Mind Mapping pada pelajaran Bahasa Indonesia dalam pembuatan puisi untuk meningkatkan kreativitas siswa. Bagi Sekolah hasil penelitian ini diharapkan dapat meningkatkan mutu pendidikan dan kualitas pembelajaran Bahasa Indonesia di sekolah, khususnya di SMA Negeri 2 Sungaiselan. Bagi Peneliti memberikan masukan dalam upaya mempersiapkan diri untuk mengajar lebih baik dalam menerapkan pembelajaran sebagai salah satu cara yang baik serta efektif sesuai dengan materi yang akan dipelajari.

Menulis atau mengarang memang mudah, tidak sulit untuk dihafal. Tetapi 
Edutainment : Jurnal Ilmu Pendidikan dan Kependidikan

Volume 8 No. 1 Edisi Januari - Juni 2020

menulis atau mengarang bukanlah sekedar teori, melainkan keterampilan. Abidin, dkk. (2017:1.3) mengemukakan bahwa "Menulis yaitu suatu kegiatan penyampaian pesan atau komunikasi melalui tulisan sebagai medianya. Tulisan merupakan simbol atau lambang bahasa yang dapat dilihat dan disepakati pemakainya”. Mulyati (2012:7.1) berpendapat bahwa "Menulis merupakan kegiatan penuangan ide dan gagasan seorang ke dalam media tulisan. Menulis adalah suatu proses berfikir dan menuangkan pemikiran itu dalam bentuk wacana (karangan)".

Dari berbagai pendapat di atas dapat disimpulkan bahwa menulis merupakan proses berfikir yang berkesinambungan (menuangkan gagasan dan perasaan) dalam bentuk tulisan yang dipergunakan untuk berkomunikasi secara tidak langsung.

Menurut Nur'aini dan Indriyani (2008:30) puisi merupakan karya sastra yang menggunakan kata - kata indah dan kaya makna. Karya sastra yang singkat, padat, dan menggunakan bahasa yang indah. Singkat karena diungkapkan tidak panjang lebar seperti prosa. Padat maksudnya puisi digarap dengan pilihan kata yang mengandung kekuatan rasa dan makna, yakni dengan memilih kata yang mempunyai majas, lambang, rima, sajak dan ungkapan yang menarik. Jadi, puisi berbeda dengan bahasa keseharian.

Sejalan dengan pendapat Sudjiman (1984:109) bahwa "Puisi merupakan ragam sastra yang bahasanya terikat oleh irama, rima, serta penyusunan larik dan bait. Puisi bebas adalah puisi yang tidak terikat oleh rima, serta tidak terikat oleh jumlah larik dalam setiap bait”. Selain itu, Rosdiana, dkk. (2009:7.11) juga menjelaskan puisi anak adalah puisi untuk dikonsumsi anak, yang isinya sesuai dengan lingkungan anak, usia anak, dan memiliki nilai - nilai yang dapat membentuk sikap, budi pekerti yang luhur, serta memiliki nilai seni. Berfungsi sebagai media anak dalam mengekspresikan apa yang dirasakan anak, menambah wawasan dan pengalaman anak serta dikemas dengan kesederhanaan bentuk, pemakaian bahasa dan gaya penyampaian secara langsung.

Berdasarkan berbagai pendapat di atas dapat disimpulkan menulis puisi adalah kegiatan menulis karya sastra yang menggunakan kata indah dan penuh makna. Menulis merupakan kegiatan yang produktif dan ekspresif, dengan menulis kreativitas siswa dapat ditingkatkan. Pada kegiatan menulis puisi, penulis harus terampil memilih kosakata dan mengembangkan kalimat. Menulis puisi merupakan bagian dari pembelajaran apresiasi sastra yang 
Edutainment : Jurnal Ilmu Pendidikan dan Kependidikan

Volume 8 No. 1 Edisi Januari - Juni 2020

harus dipahami. Menulis puisi tidak dapat dilakukan dengan cara sembarangan.

Menulis puisi hendaklah memperhatikan beberapa unsur agar puisi lebih menarik untuk dibaca dan bermakna.

Menurut Nurgiyantoro (2014:3) penilaian merupakan suatu kegiatan yang tidak mungkin dipisahkan dari kegiatan pembelajaran secara umum. Semua kegiatan pembelajaran yang dilakukan harus selalu diikuti atau disertai dengan kegiatan pembelajaran yang dilakukan seseorang guru di kelas tanpa pernah diikuti oleh adanya suatu penilaian. Tanpa mengadakan sesuatu penilaian, kita tidak mungkin dapat menilai dan melaporkan hasil pembelajaran peserta didik secara objektif.

Penilaian dilakukan berdasarkan kriteria penilaian Achmad (2016:38) sebagai berikut: 1) Tipografi, Merupakan bentuk puisi seperti halaman tidak dipenuhi kata - kata, pengaturan baris, tepi kanan kiri dan baris puisi tidak dimulai dengan huruf capital, diakhiri dengan tanda titik. 2) Diksi, Merupakan pemilihan kata - kata dalam puisi sehingga memiliki makna bias dan transparan. 3) Gaya Bahasa, Gaya bahasa atau majas merupakan penggunaan bahasa yang memiliki efek dan konotasi tertentu. 4) Kata Konkrit, Merupakan kata yang mudah dipahami oleh pembaca karena tidak memiliki makna ganda. 5) Rima, Merupakan unsur kesamaan bunyi baik di bagian awal, tengah, maupun di akhir puisi. 6) Imaji, Susunan kata yang dapa mengungkapkan pengalaman, perasaan, penglihatan, dan pendengaran.

\section{METODE PENELITIAN}

Penelitian ini menggunakan metode penelitian kualitatif deskriptif. Menurut Sugiyono (2015:25) metode penelitian kualitatif digunakan untuk memastikan kebenaran data. Sukardi (2013:157) menyebutkan penelitian deskriptif pada umumnya dilakukan dengan tujuan utama menggambarkan secara sistematis fakta dan karakteristik objek atau subjek yang diteliti secara tepat. Metode ini sangat berguna untuk mendapatkan variasi permasalahan yang berkaitan dengan tingkah laku manusia. Rancangan penelitian ini menggunakan one group posttest only design. Tahapannya, diawali dengan melakukan pengumpulan data awal dilanjutkan dengan penerapan model Mind Mapping, kemudian dilakukan pengumpulan data akhir untuk menarik kesimpulan.

Subjek penelitian ini yaitu siswa kelas XII Bahasa SMA Negeri 2 Sungaiselan yang berjumlah 20 siswa. Penelitian dilaksanakan pada bulan Februari sampai dengan April 
Edutainment : Jurnal Ilmu Pendidikan dan Kependidikan

Volume 8 No. 1 Edisi Januari - Juni 2020

2018. Objek penelitian ini yaitu karakter siswa.

Teknik pengumpulan data penelitian ini yaitu tes unjuk kerja, observasi, wawancara mendalam, dan dokumentasi. Tes unjuk kerja digunakan untuk memperoleh ciptaan puisi siswa, teknik observasi digunakan untuk mengamati kegiatan pembelajaran secara langsung, dan wawancara mendalam untuk mengetahui keefektifan penerapan model Mind Mapping dalam pembelajaran menulis puisi. Data yang terkumpul dikombinasi dalam bentuk triangulasi untuk memastikan keakuratan data.

Analisis data pada penelitian menggunakan teknik analisis secara kualitatif. Analisis data penelitian kualitatif lebih difokuskan selama proses di lapangan bersamaan dengan pengumpulan data (Sugiyono, 2015:245). Tahapan yang dilakukan dalam menganalisis data melalui tiga tahapan dengan Model Miles and Huberman yaitu reduksi data (data reduction), penyajian data (display data), dan kesimpulan (conclusion drawing/verification).

\section{HASIL DAN PEMBAHASAN}

Penanaman nilai - nilai pendidikan karakter melalui pembelajaran menulis puisi dengan menggunakan model Mind Mapping di kelas XII Bahasa SMA Negeri 2 Sungaiselan meliputi perencanaan, pelaksanaan, dan evaluasi pembelajaran.

Perencanaan Penanaman Nilai - nilai Pendidikan Karakter dalam Pembelajaran

Rencana pembelajaran yang menanamkan nilai - nilai karakter menurut Majid (2013:11) meliputi analisis kondisi awal pembelajaran, kendala pembelajaran, sumber materi pembelajaran, karakteristik siswa, dan kompetensi yang akan dicapai. Amri, dkk. (2011:65-66) juga berpendapat perencanaan pembelajaran pendidikan dalam pembelajaran meliputi perencanaan pengelolaan kelas, pengorganisasian bahan, pengelolaan kegiatan belajar mengajar, penggunaan sumber belajar, dan penilaian. Berdasarkan kedua pendapat tersebut, perencanaan yang dilakukan dalam pembelajaran ini yaitu mengumpulkan data awal: analisis kondisi awal/karakteristik siswa, kendala pembelajaran, sumber materi pembelajaran, dan menyusun instrumen penilaian.

Penanaman nilai - nilai karakter melalui pembelajaran puisi dengan menggunakan model Mind Mapping di kelas XII Peminatan Bahasa diawali dengan pengumpulan data awal. Teknik yang digunakan dalam kegiatan yaitu observasi, 
wawancara, dan dokumentasi. Hasil yang diperoleh masih minimnya nilai - nilai karakter yang muncul setelah pembelajaran usai. Hal tersebut berarti masih lemahnya penanaman nilai - nilai karakter kepada siswa. Hasil observasi diperkuat oleh hasil wawancara terhadap wali kelas XII Bahasa dan beberapa guru yang mengajar di kelas tersebut, sulitnya menanamkan nilai - nilai karakter kepada siswa, misalnya kreatif, selalu jujur, tanggung jawab yang tinggi, rasa ingin tahu, mandiri. Oleh karena itu, dapat disimpulkan bahwa siswa kelas XII Bahasa SMA Negeri 2 Sungaiselan belum menerapkan nilai - nilai karakter secara maksimal.

Berdasarkan hal tersebut, perencanaan yang disusun untuk menanamkan nilai - nilai karakter melalui pembelajaran menulis puisi dengan Model Mind Mapping sebagai berikut:

Menyusun RPP berdasarkan silabus, Rencana Pelaksanaan Pembelajaran (RPP) Mata Pelajaran Bahasa Indonesia Peminatan Kelas XII Bahasa saat proses pembelajaran sudah tersusun secara umum, terdapat KI, $\mathrm{KD}$, tujuan pembelajaran, karakter yang dikembangkan, materi pembelajaran, model dan metode pembelajaran, langkah - langkah pembelajaran, sumber belajar, dan penilaian. RPP yang disusun memuat karakter yang akan diimplementasikan dalam pembelajaran: disiplin, santun, penuh percaya diri, mandiri, jujur, dan kreatif.

Membuat rancangan pembelajaran menggunakan Model Mind Mapping, Mind Mapping atau peta pikiran merupakan sebuah peta jalan yang mempunyai banyak cabang. Melalui peta pikiran ini kita bisa membuat pandangan secara menyeluruh tentang sebuah pokok masalah dalam suatu area yang sangat luas. Dengan sebuah peta kita bisa merencanakan sebuah rute yang tercepat dan tepat dan mengetahui kemana kita akan pergi dan di mana kita berada. Kurniasih dan Berlin (2015:53) berpendapat model Mind Mapping merupakan cara untuk menempatkan informasi ke dalam otak dan mengambilnya kembali keluar otak.

Mind Mapping dalam pembelajaran berfungsi sebagai pengingat. Tugasnya mencatat suatu materi pelajaran yang memudahkan siswa untuk belajar. Menurut Saribi (2014:19) Mind Mapping atau peta pikiran yaitu sebuah diagram yang digunakan untuk mempresentasikan kata kata, ide - ide (pikiran), tugas - tugas atau hal - hal lain yang dihubungkan dari ide pokok otak. Peta pikiran juga digunakan untuk menggeneralisasikan, memvisualisasikan serta mengklafikasikan ide - ide dan sebagai bantuan dalam belajar, 
Edutainment : Jurnal Ilmu Pendidikan dan Kependidikan

Volume 8 No. 1 Edisi Januari - Juni 2020

berorganisasi, pemecahan masalah, pengambilan keputusan serta dalam menulis.

Rancangan Mind Mapping dalam pembelajaran menulis puisi diantaranya: 1) guru menyediakan kertas kosong berukuran folio atau kertas HVS A4 sebanyak 40 lembar untuk dibagikan kepada siswa masing - masing 2 lembar. 2) Guru menstimulasi siswa dengan beberapa pertanyaan: a) siapakah yang selalu datang tepat waktu?; b) apakah selalu menunaikan shalat Zuhur dan Asar berjamaah di masjid?; c) apabila rekan kalian yang beragama non muslim tertimpa musibah, apakah yang kalian lakukan?; d) Apakah selalu melaksanakan tugas piket kelas? Pertanyaan tersebut diajukan oleh guru dan dijawab oleh siswa secara lisan. 3) Guru menjelaskan kepada siswa cara termudah menciptakan puisi dengan menggunakan model Mind Mapping beserta contoh konkretnya. 4) Guru menjelaskan kepada siswa aturan aturan yang harus dipatuhi siswa selama pembelajaran: selama pembelajaran siswa harus bersikap santun, mandiri dan percaya diri serta jujur dalam menciptakan puisi sebagai karya pribadi tanpa mencontoh puisi orang lain, dan kreatif. 5) Guru memberikan waktu kepada siswa selama 60 menit untuk mencipta puisi dengan menggunakan model tersebut. 6) Ciptaan puisi tersebut dibacakan 
Edutainment : Jurnal Ilmu Pendidikan dan Kependidikan

Volume 8 No. 1 Edisi Januari - Juni 2020

dipelajari dengan karakter, h)

Menyampaikan tujuan pembelajaran.

Selanjutnya bagian 2) Inti, a) Guru menyediakan kertas kosong berukuran folio atau kertas HVS A4 sebanyak 40 lembar untuk dibagikan kepada siswa masing masing 2 lembar. b) Guru menstimulasi siswa dengan beberapa pertanyaan: siapakah yang selalu datang tepat waktu?; apakah selalu menunaikan shalat Zuhur dan Asar berjamaah di masjid?; apabila rekan kalian yang beragama non muslim tertimpa musibah, apakah yang kalian lakukan?; Apakah selalu melaksanakan tugas piket kelas? Pertanyaan tersebut diajukan oleh guru dan dijawab oleh siswa secara lisan (nilai mandiri, berpikir kreatif). c) Guru menjelaskan kepada siswa cara termudah menciptakan puisi dengan menggunakan model Mind Mapping beserta contoh konkretnya.

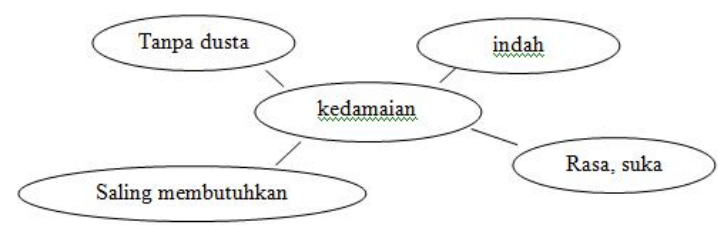

Contoh puisi:

\section{Kedamaian}

Damai itu indah
Saling membutuhkan dalam berbagi

Berbagi rasa, berbagi suka

Berpikir tanpa dusta

Menggapai indahnya mentari

Sementara itu, a) Guru menjelaskan kepada siswa aturan-aturan yang harus dipatuhi selama pembelajaran: selama pembelajaran siswa harus bersikap santun, mandiri dan percaya diri serta jujur dalam menciptakan puisi sebagai karya pribadi tanpa mencontoh puisi orang lain, dan kreatif. b) Guru memberikan waktu kepada siswa selama 60 menit untuk mencipta puisi dengan menggunakan model tersebut (nilai mandiri, tanggung jawab, kreatif). c) Ciptaan puisi tersebut dibacakan satu persatu di depan kelas dengan tertib dan santun serta percaya diri (nilai tanggung jawab, percaya diri, mandiri). d) siswa lainnya menyimak pembacaan puisi tersebut dan memberikan tanggapan (nilai saling menghargai, percaya diri, santun, kritis, logis). e) siswa dan guru melakukan refleksi untuk memperoleh pengalaman belajar yang telah dilakukan (nilai memahami kelebihan dan kekurangan).

Selanjutnya bagian 3) Penutup, a) Guru bersama dengan peserta didik membuat rangkuman/ simpulan pelajaran (nilai mandiri, kerjasama, kritis, logis); b) Guru menjelaskan lebih rinci tentang manfaat 
Edutainment : Jurnal Ilmu Pendidikan dan Kependidikan

Volume 8 No. 1 Edisi Januari - Juni 2020

pembelajaran saat ini khususnya dalam menanamkan nilai - nilai karakter (nilai disiplin, rasa ingin tahu); c) Siswa memberikan tanggapan tentang materi, saran dan kesan terhadap materi (nilai jujur, mengetahui kelebihan dan kekurangan); d) Memberikan umpan balik terhadap proses dan hasil pembelajaran. (nilai saling menghargai, percaya diri, santun, kritis, logis); e) Berdoa pada akhir pelajaran (nilai religius).

\section{Penilaian Penanaman Nilai - nilai Pendidikan Karakter dalam \\ Pembelajaran}

Penilaian merupakan kegiatan yang dilakukan untuk mengetahui keberhasilan dalam pembelajaran. Penilaian dapat dilakukan di awal, di tengah - tengah maupun di akhir pembelajaran. Penilaian dalam pembelajaran menulis puisi terbagi 2, yakni penilaian terhadap penanaman nilai pendidikan karakter (afektif) dan penilaian hasil cipta puisi (kognitif dan psikomotorik).

Pertama, penilaian terhadap penanaman nilai pendidikan karakter terlihat dari sikap/perilaku (afektif) siswa selama dan setelah pembelajaran. Hasil yang diperoleh selama pembelajaran siswa menunjukkan sikap/ perilaku yang positif. Tampak selama pembelajaran rasa ingin tahu yang tinggi sebesar $79,8 \%$, disiplin sesuai aturan yang disepakati $85 \%$, jujur dalam menulis $75,4 \%$, kreatif $74,3 \%$, mandiri dan bertanggung jawab 89\%. Hasil cipta puisi tersebut menunjukkan karakter dari para penulis, karena selama pembelajaran berlangsung siswa dituntut untuk jujur dan bertanggung jawab.

Selama pembelajaran berlangsung, terlihat kemajuan siswa baik cara bicaranya, perilaku baik di kelas maupun di luar kelas. Pada pertemuan pertama, siswa masih banyak yang terlihat bingung. Bingung memikirkan ide yang ingin ditulis dan belum terbiasa menggunakan peta pikiran ketika menulis puisi. Pada pertemuan kedua hingga ketiga, dilakukan hal yang sama, siswa diminta untuk menulis puisi, seperti pada pertemuan sebelumnya. Tampak meningkat kegiatan yang dilakukan, siswa mulai terbiasa menuangkan idenya dengan gaya masing - masing. Zuchdi (2011:4) menyatakan melalui sastra, seseorang dapat menjadi seorang dokter, guru, gelandangan, tukang becak, ulama, ronggeng, pencuri, pengkhianat, pengacara, rakyat kecil, pejabat, dan sebagainya.

Selanjutnya pada pertemuan keempat, siswa diminta untuk membacakan hasil ciptaannya di depan kelas. Tampak percaya diri, santun, disiplin, saling menghargai ketika rekan lainnya membacakan puisi di 
Edutainment : Jurnal Ilmu Pendidikan dan Kependidikan

Volume 8 No. 1 Edisi Januari - Juni 2020

depan kelas dan guru mengamati serta memberikan penilaian.

Selain itu, hasil wawancara terhadap siswa tersebut, mengaku bahwa merasa mudah mencipta puisi, hingga terbawa suasana, termotivasi untuk mencoba menggunakan model ini dalam pembelajaran lainnya. Sardiman (2007:75) mendefinisikan motivasi belajar adalah seluruh daya penggerak di dalam diri siswa yang menimbulkan kegiatan belajar yang menjamin kelangsungan dari kegiatan belajar yang memberikan arah pada kegiatan belajar sehingga tujuan yang dikehendaki oleh subjek belajar itu dapat dicapai.

\section{SIMPULAN}

Penanaman nilai - nilai pendidikan karakter melalui pembelajaran menulis puisi dengan model Mind Mapping di Kelas XII Bahasa SMA Negeri 2 Sungaiselan dilaksanakan dalam beberapa langkah, yakni perencanaan, pelaksanaan, dan penilaian dalam pembelajaran. Pertama, perencanaan meliputi: menyusun RPP berdasarkan silabus, merancang model Mind Mapping yang akan diterapkan dalam kegiatan cipta puisi. Kedua, pelaksanaan yaitu menerapkan segala sesuatu yang telah direncanakan. Pelaksanaan pembelajaran sebaiknya dilakukan lebih dari 2 pertemuan agar hasil terlihat maksimal. Selama pelaksanaan dilakukan monitoring dan evaluasi. Ketiga, penilaian meliputi penilaian terhadap penanaman nilai pendidikan karakter (afektif) dan penilaian hasil cipta puisi (kognitif dan psikomotorik).

Hasil yang diperoleh selama pembelajaran menulis puisi menggunakan model Mind Mapping untuk menanamkan nilai - nilai pendidikan karakter di kelas XII Bahasa SMA Negeri 2 Sungaiselan bahwa siswa menunjukkan sikap/perilaku yang positif. Tampak selama pembelajaran rasa ingin tahu yang tinggi sebesar 79,8\%, disiplin sesuai aturan yang disepakati $85 \%$, jujur dalam menulis $75,4 \%$, kreatif $74,3 \%$, mandiri dan bertanggung jawab 89\%. Hasil cipta puisi juga menunjukkan karakter dari para penulis, karena selama pembelajaran berlangsung siswa dituntut untuk jujur dan bertanggung jawab.

\section{DAFTAR PUSTAKA}

Abidin, Yunus, dkk. (2017). Pembelajaran Literasi. Jakarta: Bumi Aksara.

Achmad, Sri Wintala. (2016). Menulis Kreatif itu Gampang. Yogyakarta: Araska.

Astawa, I Gusti Lanang Gede Putra. (2018). Penerapan Role Playing Card untuk Menanamkan Pendidikan Karakter bagi Siswa Kelas VIC SD Negeri 1 Semarapura Tengah. Artikel tidak dipublikasikan. 
Edutainment : Jurnal Ilmu Pendidikan dan Kependidikan

Volume 8 No. 1 Edisi Januari - Juni 2020

Kurniasih, Imas dan Berlin Sani. (2015). Ragam Pengembangan Model Pembelajaran untuk Peningkatan Profesionalitas Guru. Yogyakarta: Kata Pena.

Majid, Abdul. (2013). Perencanaan Pembelajaran. Bandung: Remaja Rosdakarya.

Mulyati, Yeti. (2012). Keterampilan Bahasa Indonesia Universitas Terbuka. Banten.

Nur'aini, U., Indriyani. (2008). Bahasa Indonesia SD/MI Kelas V. Jakarta: Departemen Pendidikan Nasional.

Nurgiyantoro, B. (2014). Penilaian Pembelajaran Bahasa Berbasis Kompetensi. Yogyakarta: BPFE.

Permendikbud No. 23 Tahun 2015 tentang Penumbuhan Budi Pekerti.

Permendikbud No. 64 Tahun 2015 tentang Kawasan Tanpa Rokok di Lingkungan Sekolah.

Permendikbud No. 82 Tahun 2015 tentang Pencegahan dan Penanggulangan Tindak Kekerasan di Lingkungan Satuan Pendidikan.

Permendikbud No. 8 Tahun 2016 tentang Buku yang Digunakan oleh Satuan Pendidikan.

Permendikbud No. 18 Tahun 2016 tentang Pengenalan Lingkungan Sekolah.
Rosdiana, Yusi, dkk. (2009). Bahasa dan Sastra Indonesia di SD. Jakarta: Universitas Terbuka.

Salahudin, Anas. (2013). Pendidikan Karakter Pendidikan Berbasis Agama dan Budaya Bangsa. Bandung: CV. Pustaka Setia.

Sardiman. 2007. Interaksi dan Motivasi Belajar Mengajar. Bandung: Rajawali Pers.

Saribi, KMS Humaram. (2014). Peningkatan Kemampuan Menulis Karangan Deskripsi dengan Penerapan Metode Mind Mapping paa Kelas V SDN 55 Kota Bengkulu. Skripsi. Program Studi Pendidikan Guru Sekolah Dasar, FKIP Universitas Bengkulu.

Sudjiman, Panuti. (1984). Kamus Istilah Sastra. Jakarta: PT. Gramedia.

Sugiyono. (2015). Metode Penelitian Pendidikan Pendekatan Kuantitatif, Kualitatif, dan $R$ dan D. Bandung: Alfabeta.

Sukardi. (2013). Metodologi Penelitian Pendidikan Kompetensi dan Praktiknya. Jakarta: Bumi Aksara.

Zuchdi, Darmiyati. (2011). "Bahasa dan Sastra Indonesia sebagai Wahana Pendidikan Karakter" dalam Pendidikan Karakter dalam Perspektif Teori dan Praktik (Darmiyati Zuchdi ed.). Yogyakarta: UNY Press. 